\title{
Dynamic Hip Screw and Proximal Femoral Nailing As a Surgical Treatment of Peritrochanteric Fracture of Femur-A Comparative Study
}

\author{
${ }^{1}$ Dr. Sanjeev Kumar Singh, ${ }^{2}$ Dr. Sanjeev Kumar Hembram, ${ }^{3}$ Dr. Anjali Singh, \\ ${ }^{4}$ Dr Prof. Subrata Nag \\ ${ }^{1}$ Assistant Professor, Orthopedics, Narayan Medical College,Sasaram,Bihar, \\ ${ }^{2}$ Senior Resident,Orthopedics, NMCH,Sasaram, Dr. NIPENDRA KISHORESenior Resident,NMCH, \\ ${ }^{3}$ Senior Resident,Pediatrics dept.NMCH. \\ ${ }^{4} \mathrm{HOD}$ Anesthesiology, $\mathrm{NMCH}$.
}

\section{Introduction}

Fractures of limb especially the lower limb bring tough time not only for the patient but for the entire family owing to prolong immobilization and disability.

Early restoration of joints motion with a stable fixation of fracture, return to normal physiological function and minimal morbidity is now regarded as ideal fracture treatment Peritrochanteric/intertrochanteric fractures are of intense interest globally.

Peritrochanteric area includes part of femur from extracpasular part of neck to a point $5 \mathrm{~cm}$. distal to lesser trochanter. It can be divided in to Intertrochanteric Area between greater and lesser trochanter of femur and subtrochanteric area $5 \mathrm{~cm}$. below lesser trochanter. Being a transition zone between neck and shaft of femur and cancellous bone, this area has different fracture characteristic. Weight bearing is also unequally distributed throughout this area. Medial comminution influence influences the fracture stability and treatment outcome.

Peritrochanteric fracture can be stable or unstable depending on integrity of posteromedial cortex and pattern of fracture. Evans in 1949 described about stability of Peritrochanteric fracture, according to him in stable fracture posteromedial cortex remains intact or has minimal comminution. Unstable fracture on other hand has greater comminution of posteromedial cortex. Although they are inherently unstable these fracture can be converted in to a stable reduction if medial cortex apposition is obtained. Reverse oblique pattern of fracture is also unstable type of fracture.

\section{Aims And Objective}

Aim:

The main aim is to obtain union of fracture in most anatomical position compatible with maximal functional return of the extremity, decrease the mortality, reduce the duration of hospital stay, mobilize the patient early and to prevent bed ridden complications.

Objective:

Compare the result of dynamic hip screw and Proximal Femoral Nailing as a surgical treatment of peritrochanteric fracture of femur.

To study the outcome of the procedure, with respect to early mobilization and return to prefracture ambulatory status.

Assessment of results based on subjective parameters (like pain, ability to squat or sit cross legged and walking), objective parameters (like deformity, range of movements of the hip and limb length) and radiological findings (like fracture union, consolidation, neck shaft angle and position of the implant), after clinical and radiological union, and comparison with previous studies.

\section{Source Of Data:}

\section{Material \& Methods}

The material for the present study was obtained from the patients admitted in Katihar Medical College, Katihar, with the diagnosis of peritrochanteric fracture femur.. The patients were randomly selected on first come and first inclusion basis. The patients admitted were taken for prospective study. A minimum of 30 cases were taken and the patients were informed about the study in all respects and informed consent was obtained from each patient. 


\section{Method Of Collecton Of Data}

- By interview

- By follow up at intervals of $6,12,18$, and $24^{\text {th }}$ week

- By clinical examination

- By analyzing case papers

\section{Inclusion criteria:}

1. Patient who has been diagnosed as having intertrochanteric fractures.

2. Adult patient 21 years of age and above, Sex - Both male and female.

3. Patient who are fit for surgery.

\section{Exclusion criteria:}

1. Patients unfit for the surgery.

2. Patients with compound fractures.

3. Patients with pathological fractures.

4. Patients admitted for re-operation.

5. Patient not given written consent for surgery.

\section{Pre-Operative Evaluation}

Patients admitted with Peritrochanteric fracture were examined meticulously; detailed history was taken and investigated with X-ray pelvis with both hips AP and Lateral view. X-Rays were reviewed and classified according to Boyd and Griffin's and Evans classification. Skin traction was applied to all cases. The required information was recorded in the proforma prepared. Blood and urine examinations were ordered as follows:

\section{Investigations}

- $\quad$ Blood - $\mathrm{Hb} \%$, Total count, Differential count, E.S.R.

- Urine - Albumin, Sugar, microscopy.

- Blood grouping and Rh type

- BT, CT.

\section{Special Investigations}

- HIV1\&2, HbsAg, HCV

- Blood urea

- Serum Creatinine

- Blood sugar Level

- ECG

- Chest X -ray

\section{Observation}

The study involved 30 confirmed cases of Peritrochanteric femur of either sex. Out of 30 cases, 15 were treated by a dynamic hip screw \& 15 were treated by proximal femoral nail. The analysis of the patient data, intra operative data $\&$ post operative outcome is as follows.

\section{Side Of Limb Involved In Peritrochanteric Fracture Of Femur Study Group}

\begin{tabular}{|l|c|c|c|c|}
\hline \multirow{2}{*}{ Side of limb } & \multicolumn{2}{|c|}{ PFN } & \multicolumn{2}{c|}{ DHS } \\
\cline { 2 - 5 } & $\begin{array}{l}\text { Number of } \\
\text { Patients }\end{array}$ & $\begin{array}{c}\text { Percentage } \\
(\%)\end{array}$ & $\begin{array}{c}\text { Pumber of Patients } \\
(\%)\end{array}$ \\
\hline Right & 8 & 53.33 & 6 & 40 \\
\hline Left & 7 & 46.67 & 9 & 60 \\
\hline Total & 15 & 100 & 15 & 100 \\
\hline
\end{tabular}

Time Interval Between Injury And Operation In Study Group

\begin{tabular}{|l|c|c|c|c|}
\hline \multirow{2}{*}{ Time interval } & \multicolumn{2}{|c|}{ Number Of Cases } & \multicolumn{2}{c|}{ Percentage (\%) } \\
\cline { 2 - 5 } & PFN & DHS & PFN & DHS \\
\hline Within 1 week & 11 & 8 & 73.33 & 53.33 \\
\hline 1 to 2 wks. & 4 & 5 & 26.67 & 33.33 \\
\hline Between 2 to 4 wks & 0 & 2 & 00.00 & 13.33 \\
\hline Total & 15 & 15 & 100 & 100 \\
\hline
\end{tabular}


Operative Time For Fixation Peritrochanteric Fracture Of Femur By P.F.N And D.H.S In Study Group

\begin{tabular}{|l|c|c|c|c|}
\hline \multirow{2}{*}{$\begin{array}{c}\text { Operative Time } \\
\text { (min.) }\end{array}$} & \multicolumn{2}{|c|}{ PFN } & \multicolumn{2}{c|}{ DHS } \\
\cline { 2 - 5 } & No. of Patients & \% & No. of Patients & \% \\
\hline $\mathbf{6 0}-\mathbf{9 0}$ min. & 3 & 20.00 & 2 & 13.33 \\
\hline $\mathbf{9 0}-\mathbf{1 2 0}$ min. & 10 & 66.67 & 9 & 60.00 \\
\hline $\mathbf{1 2 0}-\mathbf{1 5 0}$ min. & 2 & 13.33 & 4 & 26.67 \\
\hline Total & 15 & 100 & 15 & 100 \\
\hline
\end{tabular}

Condition Of Incision Site After Stitch Removal In Dhs And Pfn Group

\begin{tabular}{|l|c|c|c|c|}
\hline \multirow{2}{*}{ Time interval } & \multicolumn{2}{|c|}{ Number Of Cases } & \multicolumn{2}{c|}{ Percentage (\%) } \\
\cline { 2 - 5 } & PFN & DHS & PFN & DHS \\
\hline Within 1 week & 11 & 8 & 73.33 & 53.33 \\
\hline 1 to 2 wks. & 4 & 5 & 26.67 & 33.33 \\
\hline Between 2 to 4 wks & 0 & 2 & 00.00 & 13.33 \\
\hline Total & 15 & 15 & 100 & 100 \\
\hline
\end{tabular}

Average Duration Of Hospital Stay In Dhs And Pfn Group

\begin{tabular}{|l|c|c|}
\hline \multirow{2}{*}{ Stable } & Average Hospital Stay( In Days) \\
\cline { 2 - 3 } & PFN & DHS \\
\hline Unstable & 18 & 26 \\
\hline Subtrochanteric & 21 & 28 \\
\hline
\end{tabular}

Clinical Union Based On Tenderness And Swelling In Dhs And Pfn Group

\begin{tabular}{|c|c|c|c|c|c|c|c|c|}
\hline \multirow{4}{*}{$\begin{array}{l}\text { Post-operative } \\
\text { Weeks }\end{array}$} & \multicolumn{8}{|c|}{ Number of Patients } \\
\hline & \multicolumn{4}{|c|}{ swelling } & \multicolumn{4}{|c|}{ Tenderness } \\
\hline & \multicolumn{2}{|c|}{ PFN } & \multicolumn{2}{|c|}{ DHS } & \multicolumn{2}{|c|}{ PFN } & \multicolumn{2}{|c|}{ DHS } \\
\hline & Absent & Present & Absent & Present & Absent & Present & Absent & Present \\
\hline $6^{\text {th }}$ Week & 12 & 3 & 10 & 5 & 13 & 2 & 3 & 12 \\
\hline $12^{\text {th }}$ Week & 14 & 1 & 12 & 3 & 14 & 1 & 12 & 3 \\
\hline $18^{\text {th }}$ Week & 15 & Nil & 15 & Nil & 15 & Nil & 15 & Nil \\
\hline $24^{\text {th }}$ Week & 15 & Nil & 15 & Nil & 15 & Nil & 15 & Nil \\
\hline
\end{tabular}

\section{Radiological Union In Dhs And Pfn Group}

\begin{tabular}{|c|c|c|c|c|c|c|c|c|}
\hline \multirow{3}{*}{ Amount of Callus } & \multicolumn{8}{|c|}{ Number of Patients } \\
\hline & \multicolumn{3}{|c|}{ PFN } & & \multicolumn{3}{|c|}{ DHS } & \\
\hline & $\begin{array}{l}6^{\text {th }} \\
\text { Wk. }\end{array}$ & $12^{\text {th }} \mathrm{Wk}$ & $18^{\text {th }} \mathrm{Wk}$. & $24^{\text {th }}$ Wk. & $6^{\text {th }} \mathrm{Wk}$. & $12^{\text {th }} \mathrm{Wk}$. & $18^{\text {th }} W k$. & $24^{\text {th }}$ Wk. \\
\hline No Visible Callus & 1 & - & - & - & 1 & - & - & - \\
\hline Little Amount of Callus & 8 & 1 & - & - & 9 & 2 & - & - \\
\hline Fair Amount of Callus & 6 & 10 & 1 & - & 5 & 9 & 1 & - \\
\hline Good Amountof Callus & - & 4 & 14 & 15 & - & 4 & 14 & 15 \\
\hline
\end{tabular}

Range Of Movement At Joints At The End Of $24^{\text {th }}$ Week In Pfn And Dhs Group

\begin{tabular}{|l|c|c|c|c|}
\hline \multirow{2}{*}{$\begin{array}{l}\text { Range of Movement } \\
\text { at Hip }\end{array}$} & \multicolumn{2}{|c|}{ PFN } & \multicolumn{2}{c|}{ DHS } \\
\cline { 2 - 5 } & $\begin{array}{l}\text { No. of } \\
\text { Patients }\end{array}$ & $\mathbf{\%}$ & No. of Patients & \% \\
\hline$<\mathbf{9 0}^{\mathbf{0}}$ & Nil & 00.00 & Nil & 00.00 \\
\hline $\mathbf{0}^{\mathbf{0}}-\mathbf{1 1 0}^{\mathbf{0}}$ & 1 & 06.66 & 1 & 06.66 \\
\hline $\mathbf{0}^{\mathbf{0}}-\mathbf{1 3 0}$ & 1 & 06.67 & 4 & 26.67 \\
\hline Full & 13 & 86.67 & 10 & 66.67 \\
\hline Total & 15 & 100 & 15 & 100 \\
\hline
\end{tabular}

Range Of Movement At Knee At The End Of 24th Week

\begin{tabular}{|l|l|l|l|l|}
\hline \multirow{2}{*}{$\begin{array}{l}\text { Range of Movement } \\
\text { at Knee }\end{array}$} & PFN & DHS & \% \\
\cline { 2 - 5 } & No. of Patient & \% & No. of Patient & Nil \\
\hline $\mathbf{9 0}^{\mathbf{0}}$ & Nil & 00.00 & Nil & 00.00 \\
\hline $\mathbf{0}^{\mathbf{0}}-\mathbf{1 1 0}^{\mathbf{0}}$ & Nil & 00.00 & 4 & 00.00 \\
\hline $\mathbf{0}^{\mathbf{0}}-\mathbf{1 3 0}^{\mathbf{0}}$ & 3 & 20.00 & 11 & 26.67 \\
\hline Full & 12 & 80.00 & 15 & 73.33 \\
\hline Total & 15 & 100 & & 100 \\
\hline
\end{tabular}

Complication In Dhs And Pfn Group

\begin{tabular}{|c|c|c|}
\hline \multirow[t]{2}{*}{ Complication } & \multicolumn{2}{|c|}{ Number of Patients } \\
\hline & PFN & DHS \\
\hline 1) No Complication & 11 & 9 \\
\hline
\end{tabular}


Dynamic Hip Screw and Proximal Femoral Nailing As a Surgical Treatment of .....

\begin{tabular}{|ll|l|l|}
\hline 2$)$ & Shortening & Nil & 2 \\
\hline 3$)$ & Coxa Vara & Nil & 3 \\
\hline 4$)$ & Coxa Valga & Nil & Nil \\
\hline 5$)$ & Pain Around Nail Insertion site & 2 & Nil \\
\hline 6$)$ & Internal Rotation of Limb & Nil & Nil \\
\hline 7$)$ & External Rotation of Limb & 1 & Nil \\
\hline 8$)$ & Infection & 1 & \\
$\bullet$ & Superficial & Nil & 2 \\
$\bullet \quad$ Deep & Delayed Union & Nil \\
\hline 9) & Nil & Nil \\
\hline \multicolumn{1}{|l|}{ 10) Non Union } & Nil & Nil \\
\hline 11) Screw cut out & Nil & Nil \\
\hline 12) Fracture of Proximal Femur & Nil & Nil \\
\hline 13) Broken Implant & Nil & Nil \\
\hline 14) Bending of Screw & Nil \\
\hline
\end{tabular}

\section{Discussion \& Conclusion}

In patients with peritrochanteric fracture union is not a problem if left untreated it generally unite because intertrochanteric area is the area of cancellous bone. If treated conservatively coxa vara deformity, shortening develops. Thus with the time in the last 3-4 decades treatment of intertrochanteric fractures has changed significantly. Treatment of peritrochanteric fracture has moved from conservative to operative side. Closed reduction and internal fixation of peritrochanteric fracture is the treatment of choice now a day. A large number of fixation implants has been devised and discarded. Differences still exist regarding the type of implant to be used. The treatment still merits the type of fracture and condition of patient.

In the present prospective study 30 patients of either sex with peritrochanteric fractures were studied. 15 had been treated by Proximal Femoral Nail and rest fifteen by Dynamic Hip screw and Plate irrespective of age, sex, and nature of fracture. The data collected in this study is assessed, analyzed, compared with other series and the results were evaluated.

\section{Nail Or Plate}

- The sliding hip screw with plate remained the gold standard for fixation of intertrochanteric fractures for years. With the arrival of the intra medullary hip screw it was thought that the sliding hip screw would be replaced forever, however this is not true the intra medullary hip screw has its own set of complications, more exposure to radiation, a higher learning curve \& all at a higher cost.

- The dynamic hip screw is still the implant of choice in the stable types of intertrochanteric fractures. If the proper intra operative guide lines are adhered to then the results in this group of patients is excellent

- In the more unstable types of fracture the intra medullary hip screw has distinct advantages over the plate \& should be the preferred implant for fixation. The need to achieve an anatomical reduction is mandatory since there is less sliding with this implant. Any gap on the post operative X-rays could always lead to a future non -union.

- In conclusion both the implants are here to stay, it is the fracture geometry \& bone quality which will influence the choice of fixation. The quality of the reduction \& proper positioning of the implant are the keys to achieving the best postoperative out come.

\section{References}

[1]. Evans E. The treatment of intertrochanteric fractures of the femur. . J Bone Joint Surg Br 1949; 31:190-203.

[2]. Gulberg B, Jhonell O, Kanis J. Worldwide projection for hip fractures. Osteoporos Int 1997: 7:407-413.

[3]. Melton $\mathrm{Lj} 3^{\text {rd }}$, Kearns AE, Atkinson EJ et al. Secular trends in hip fracture incidence and recurrence . Osteoporos Int. 2009; 20(5): 687-694.

[4]. Hagino H, Furukawa K, Fujiwara S, et al. Recent trends in incidence and lifetime risk of hip fracture in Tottori, Japan Osteoporos Int. 2009; 20(4):543-548

[5]. Gallgher JC, Melton LJ, Riggs BL, Bergath E. Epidemiology of the fractures of the proximal femur in Rochester, Minnesota. Clin orthop 1980; 150:163-171.

[6]. Hinton RY, Smith GS. The association of age, race \& sex with the location of proximal femoral fractures in the elderly. . J Bone Joint Surg Am 1993.

[7]. Hedlund R, Lindgren U, Ahlbom A. Age \& Sex specific incidence of femoral neck \& trochanteric fractures: an analysis based on 20,358 fractures in Stockholm County, Sweden 1972-1981. Clin orthop 1987; 222:132-139.

[8]. Cummings S, Black D, Nevitt M. Bone Density at various sites for predilection of hip fractures. Lancet 1993; 341:72-75.

[9]. Koval KJ, Zuckerman JD. Hip fractures: a practical guide to management. New York: Springer-Verlag; 2000.

[10]. Erikson SAV, Wilde TL. Bone mass in women with hip fracture. Acta Ortho Scand 1988; 59:19-23.

[11]. Cummings S, Nevitt Mc. Non skeletal determinants of fractures: the potential importance of the mechanics of falls. Osteoporosis Int 1994: 4(suppl 1):67-70.

[12]. Bucholz RW, Heckman JD, Koval KJ, Zukerman JD. Rockwood \& Green's fractures in adults. $7^{\text {th }}$ ed .Philadelphia: Lippincot Williams \& Wilkins; 2009 . 